専門医症例報告

\title{
インプラント補綴により咀嚼機能の回復を行った下顎両側遊離端欠損症例
}

塚野 寛久

\section{A Report of Improvement of Masticatory Function in a Bilateral Mandibular Free-End Case by Implant Prostheses.}

\author{
Hirohisa Tsukano
}

\begin{abstract}
抄 録
症例の概要：患者は初診時 80 歳の男性。右下・左上大臼歯部の排膿および左下可撤性義歯部の咀嚼困難 を主訴に来院。 $767, \longdiv { 4 5 6 } ， 6 7$ 部はインプラントを支台とした固定性補綴装置にて治療を行った。咀 嚼機能の変化を客観的に評価するため, 咀嚼能力值および最大咬合力を測定した，測定は術前・最終補綴 装置装着時・5 年経過時に行った。

考察：術前に比較して, 最終補綴装置装着時および 5 年経過後の咀嚼能力值・最大咬合力が大幅に改善 していることから，良好な予後が得られていると考えられる。

結論：下顎両側遊離端欠損症例に対し，インプラントを用いて咬合支持の再建を行い，咀嚼障害を改善す ることができた。
\end{abstract}

和文キーワード

インプラント，遊離端欠損，咀嚼機能

\section{ABSTRACT}

Patient: The patient was an 80-year-old male at the first visit. Chief complaints were pus discharge from the area of the mandibular right molars and maxillary left molars and difficulty in mastication with removable partial dentures on the mandibular left premolars and first molar. He was treated with fixed partial dentures (FPD) supported by implants in the concerned area. Masticatory ability and maximum occlusal force were measured to evaluate the masticatory functions. The measurements were completed before the implant treatment, at the time of the definitive prostheses delivery and at the 5-year follow-up visit.

Discussion: Masticatory ability and the maximum occlusal force with the definitive prostheses were improved from those in the preoperative state, and maintained at the 5-year follow-up visit. The results indicated that a good prognosis was obtained.

Conclusion: The masticatory functions of the patient were improved with the implant prostheses on the bilateral mandibular free-end missing areas.

\section{Key words}

Implant, free-end, masticatory functions 


\section{I. 緒 言}

従来より，遊離端欠損の補綴には可撤式の部分床義 歯が多く用いられてきたが, 違和感や審美性, 咀嚼能率 の低さから，患者の十分な満足が得られない場合や，非 圧変位量の差や支台歯の負担過重により良好な予後が 期待できないような症例を経験することがある。今回， 下顎両側遊離端欠損に対し，インプラントによる補綴 治療を行い，良好な機能回復を得た 1 症例を報告する.

\section{II. 症例の概要}

患者：初診時 80 歳, 男性.

初診 : 2006 年 2 月 2 日.

主訴：歯茎が腫れる，入れ歯の部分が噛みづらい。 既往歴：本態性高血圧，労作性狭心症。これらの疾患 は内科にてコントロールされており $(130 / 75 \mathrm{mmHg})$, 内科主治医への対診の結果，歯科処置を行ううえで問 題ないとのことであった。外科処置時は歯科麻酔科処 置室にて全身モニタリング下にて行うこととした。

現病歴：2002 年 5 月に近医にて 4 に磁性アタッチ メントを装着し，片側処理のマグネットオーバーデン

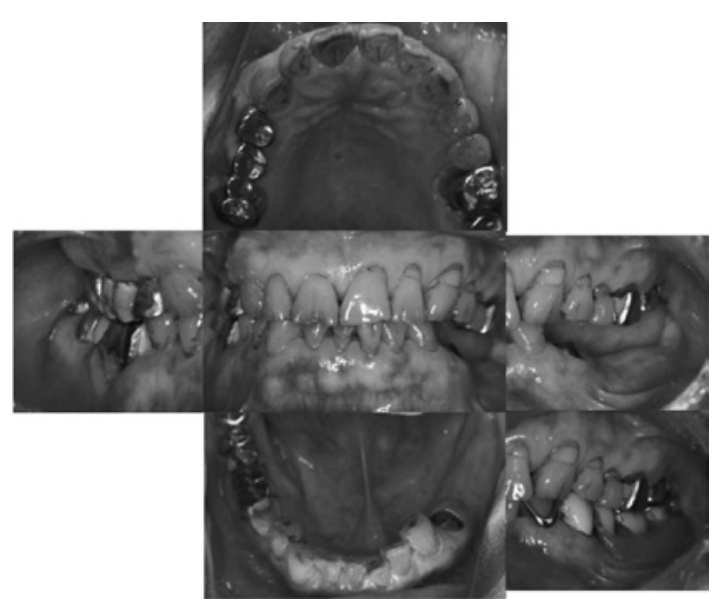

図 1 Intraoral view at the first visit 初診時口腔内写真

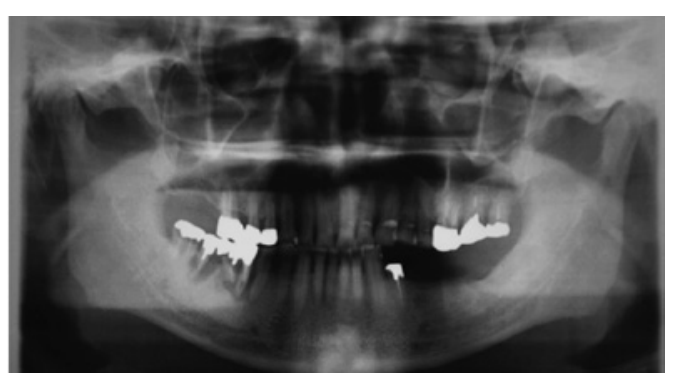

図 2 Panoramic radiography at the first visit 初診時パノラマエックス線画像
チャーを作製。2004 年 10 月，右下および左上鼠歯部 の腫脹，疼痛を訴え，近医を受診。投薬および切開処 置を受けるが度々腫脹を繰り返していた。2006 年2月, 症状に改善がみられず，左下もしっかり噛めないため, セカンドオピニオンを求め当院初診。

現症 : 初診時の口腔内写真, パノラマエックス線画 像および歯周組織検査表を図 1，図 2，表 1 に示す。 76 6は歯根破折しており排膿している状態であった。 5は補綴装置が脱離しており，エックス線画像より根 尖病巣が認められた。 4 はポケットが $5 \mathrm{~mm}$ であり, 補綴装置のマージン部二次カリエスは歯肉縁下深い部 分まで達していた。 67 は排膿しており歯周組織検査 では $9 \mathrm{~mm}$ に及ぶポケットがあり重度の辺縁性歯周炎 および歯肉緑下齟蝕に罹患していた。

診断： 76 歯根破折および 4567 義歯不適合によ る咀嚼障害.

問題点 :

(1) 76 , 67 抜歯後の欠損による咬合支持の減少.

(2) 761,67 以外の軽〜中程度の辺縁性歯周炎.

(3) 片側処理された可撤性義歯の咀嚼能力の低さ

治療方針：患者に可撤性の部分床義歯による補綴と インプラントによる固定性補綴のメリット・デメリッ トを含め説明を行ったところ，「インプラントによる 固定性の補綴」を希望した。インフォームド・コンセ ントの結果，（1） $76 ， 67 ， 4$ 抜歯，（2）全顎的歯 周治療，（3）5根管治療および歯冠修復治療，(4) イ ンプラントによる咬合支持の再建を行うことに患者の

表 1 The periodontal chart at the first visit 初診時歯周組織検査表
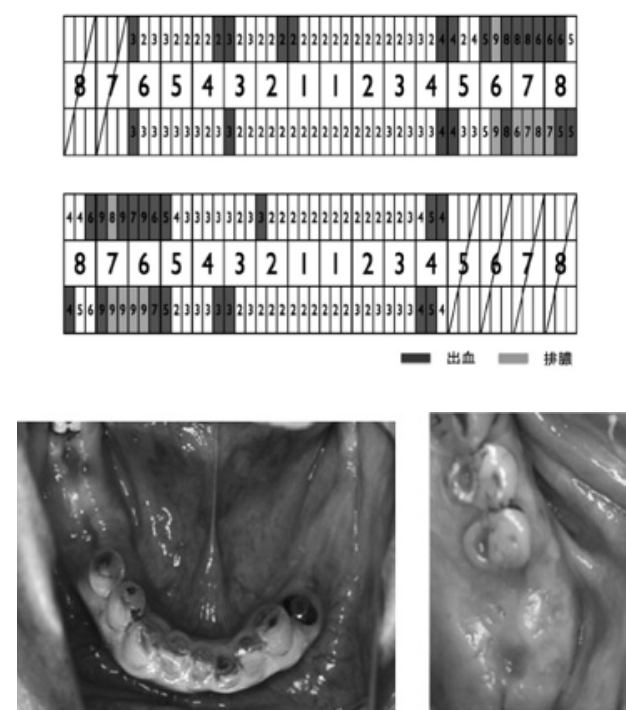

図 3 Intraoral view before implantation 術前口腔内写真 
同意を得た。

\section{III．治療内容と経過}

\section{1. 治療内容}

2006 年 2 月に歯周基本治療および 7 6 ， 6 7抜歯を 行い，2006 年 3 月，5根管治療後ファイバーポスト にて支台築造，プロビジョナルレストレーションを装 着した。2006 年 5 月に画像検査用ステントを作製し パノラマエックス線撮影および CT 撮影を行った。イ ンプラント手術前の口腔内写真を図 3 に示す。 2006 年 6 月，静脈内鎮静法下にて $76,64,456$ イン プラント（ストローマンインプラント， straumann

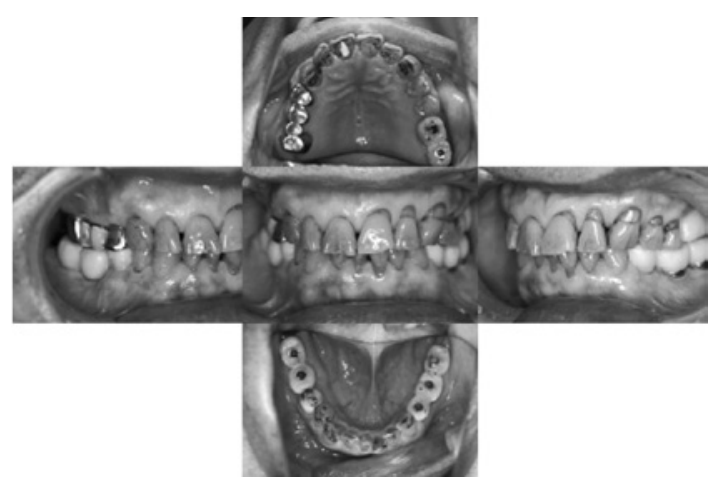

図 4 Intraoral view at the provisional restoration プロビジョナルレストレーション装着時口腔内写真

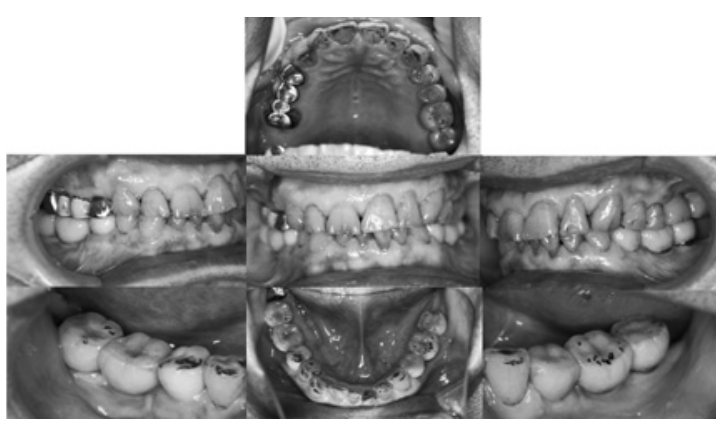

図 5 Intraoral view after final prostheses 最終補綴装置装着時口腔内写真

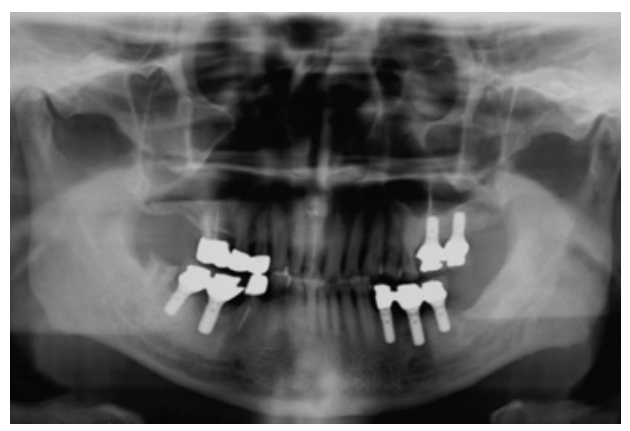

図 6 Panoramic radiography after final prostheses 最終補綴装置装着時パノラマエックス線画像
社，スイス）の埋入手術を行った。インプラントのサ イズは埋入部位の骨幅および歯槽骨一下顎管もしくは 上顎洞底間距離を考慮し $7 \mid, 67 ， 66$ 相当部には直径 $4.8 \mathrm{~mm}$ ，長径 $8 \mathrm{~mm}, \overline{6}$, 5相当部には直径 $4.8 \mathrm{~mm}$, 長径 $10 \mathrm{~mm}, \sqrt{4}$ 相当部には直径 $4.1 \mathrm{~mm}$, 長径 $10 \mathrm{~mm}$ を選択した。埋入の際はサージカルステントを 用い，初期固定は良好であった。2006 年 8 月に 7 6 , 456 プロビジョナルレストレーション，2006 年 11 月に 67 プロビジョナルレストレーションを装着した (図 4)。2007 年 3 月に5 5 ハイブリッドレジン前装冠を 装着し 2007 年 4 月に 76 6，6 7，456にスクリュー 固定式ハイブリッドレジン前装冠装着を行い，メイン テナンスに移行した（図 5, 図6)。

\section{2. 経 過}

最終補綴装置装着後 3 カ月ごとの定期的なメインテ ナンスを行っている。メンテナンス時にはプラークコ ントロール, 上部構造の破損の有無, 咬合状態, 周囲 軟組織状態, 周囲骨の変化の有無，スクリューの緩み が無いか等を口腔内およびエックス線画像にて確認し ている。現在，最終補綴装置装着後 5 年以上が経過し ているが，インプラント周囲粘膜や骨組織に異常は認 められない（図 7, 図 8)。また，口腔内状態にも変化

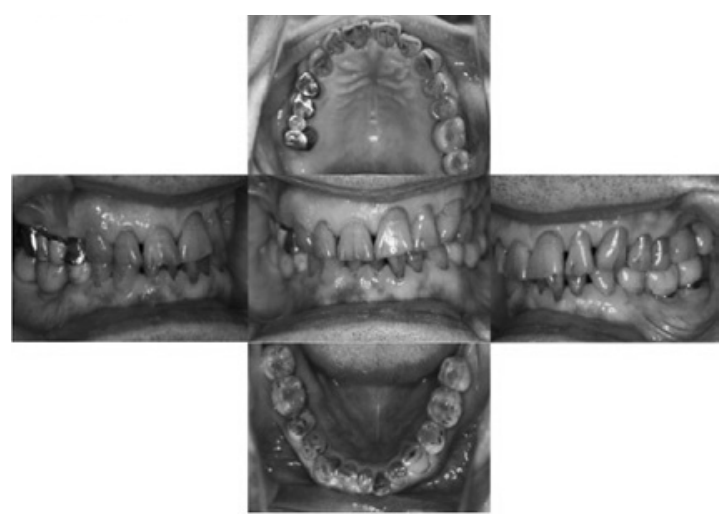

図 7 Intraoral view at five years 5 年経過時口腔内写真

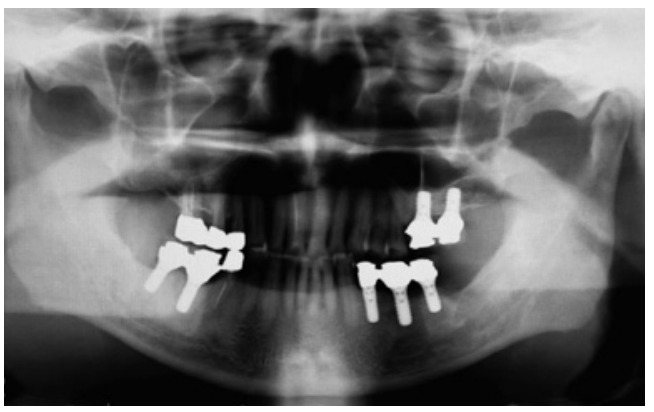

図 8 Panoramic radiography at five years 5 年経過時パノラマエックス線画像 


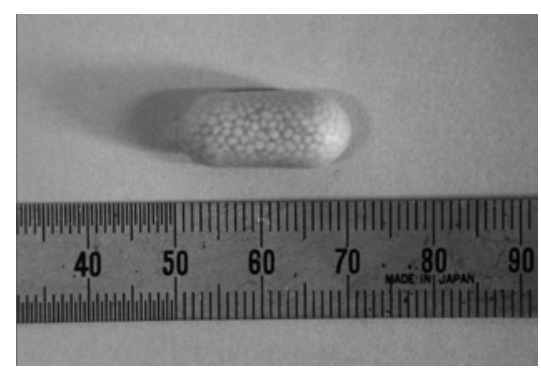

図 9 Artificial capsules

人工試料カプセル

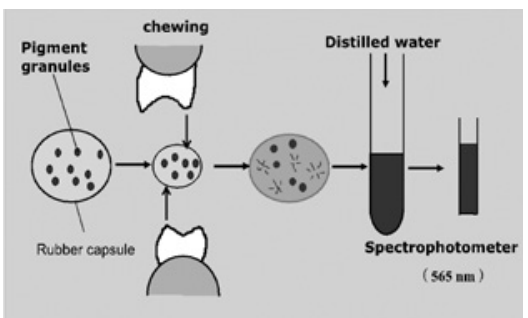

図 10 The measurement of masticatory ability using artificial capsules

人工試料カプセルによる咀嚼能力值の測定

は無く安定しており，患者は噛めるようになったと満 足している。人工試料カプセル ${ }^{1)}$ (図 9, 図 10) を用 いた咀嚼能力の測定值が右側術前 $0.006 \mathrm{~J}$ から最終補 綴装置装着後 $0.103 \mathrm{~J}, 5$ 年経過時においては $0.112 \mathrm{~J}$, 左側術前 $0.002 \mathrm{~J}$ から最終補経装置装着後 $0.082 \mathrm{~J}, 5$ 年経過時においては $0.097 \mathrm{~J}$ となった。また最大咬合 力の測定においては右側術前 $19.96 \mathrm{~kg}$ から最終補綴装 置装着後 $38.26 \mathrm{~kg} ５$ 年経過時においては $37.34 \mathrm{~kg}$, 左側術前 $9.0 \mathrm{~kg}$ から最終補経装置装着後 $31.6 \mathrm{~kg}, 5$ 年経過時においては $33.2 \mathrm{~kg} へ$ と幅な改善がみられ た（図 11，図 12）（最大咬合力の測定にはオクルーザ ルフォースメーター GM10；長野計器株式会社製を使 用した)。これらのことから客観的にも咀嚼機能が回復 してきていることが評価できる。

\section{IV. 考 察}

術前の問診による患者の主咀嚼側は右側であり，咀 嚼能力值も右側が高い值となっている。しかしながら 最大咬合力の值は左側が高く出ている。これは左側の 片側処理された部分床義歯が維持力・把持力ともに弱 いため動摇し咀嚼できにくい状態であったことと，右 下臼歯部が歯根破折しているため垂直的な強い力で咬 合できなかったことが原因と考えられる。

また，審美的な理由や咬合の付与のしやすさを考慮 するとセメント固定式の上部構造が有利となる可能性 は高いが，さまざまな偶発症により補綴装置の修理

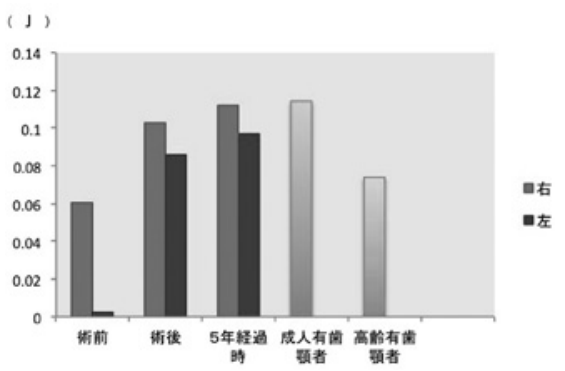

図 11 Change over time of the Masticatory ability 咀嚼能力值の経時的変化

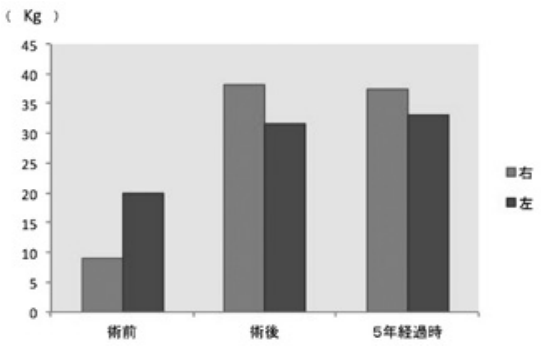

図 12 Change over time of the maximum occlusal force 最大咬合力の変化

および再製作が必要になった場合のリトリーバビリ ティ2を考え，本症例においてはスクリュー固定式の 上部構造を選択した。

\section{V. 結 論}

今回，両側遊離端欠損に対して，インプラントを用 いて咬合支持の再建を行ったことで Eichner 分類にお ける stage B2から stage Aへと口腔内状態は回復した。 それにより咀嚼機能の大幅な改善を得ることができ, 咬合の更なる崩壊を止め, 安定した口腔内状態を得る ことができた。今後も継続してメインテナンスを行い, 咬合関係および周囲組織の経過を注意深く観察してい きたい.

\section{文献}

1) Nakasima A, Higashi K, Ichinose M. A new, simple and accurate method for evaluating masticatory ability. J Oral Rehabil 1989; 16: 373-380.

2）池上龍朗，松下恭之，澤江義則，古谷野 潔，インプラ ント上部構造のリトリーバビリティに関する研究一仮着 用セメントの混和比が維持力と浮き上がり量に及ぼす影 響一。 日腔インプラント誌 2006; 19: 185-192.

著者連絡先：塚野 寛久

干 812-8582 福岡市東区馬出 3-1-1

Tel: 092-642-6371

Fax: 092-642-6374

E-mail: tsukano@dent.kyushu-u.ac.jp 